\title{
"I Thought of the Money that We Could Use": Iowa Women and Industrial Wage Work, 1950-1970
}

\section{COREEN DERIFIELD}

AS A YOUNG GIRL growing up on a farm, Pauline Fisher never dreamed that she would spend a lifetime working in a factory. She married young, shortly after high school, and followed her husband to California during World War II. They returned to Iowa when the war was over and began renting land outside of Oskaloosa. They settled down to raise a family, but their dreams of thriving on the bounty of the land faded as the harsh realities of farming in the 1950s prevented them from purchasing their farm. Unable to save enough money, they continued to rent, making farming - an already challenging lifestyle-even more difficult. Fisher lamented the hardships of farming. "By the time you give the landlord half [of the income], you didn't have much left." To keep her family together, she took a job at the Ideal Manufacturing plant in Oskaloosa, 20 miles away. She worked 40 hours per week on third shift, sometimes coming home in the mornings to help on the farm. At first, Fisher hated her job and revolted at the idea of working in a factory, but she did not have much choice. "I had to work," Fisher recalled. "Our farm just wasn't paying at all." Despite the long, hard hours, she eventually enjoyed her job, the friendships

THE ANNALS OF IOWA 73 (Winter 2014). (C) The State Historical Society of Iowa, 2014. 
she developed with other female workers, and the ability to make a decent income. ${ }^{1}$

Fisher's life illustrates the postwar trend of Iowa women leaving the farm and heading to work in a factory. She exemplifies the unusual combination of rural life and industrial work that a segment of Iowa's female population experienced in the 1950s. A confluence of events after World War II caused many Iowa women to leave the comfort of home and begin working in factories, workplaces where many of them had never intended to spend the majority of their working lives. This article demonstrates how a national movement of women working outside the home converged with an industrial boom in the state to spark tremendous growth in the number of Iowa women working in manufacturing between 1950 and 1970.

THE GROWTH in the number of Iowa women working outside the home in the 1950s was remarkable, but it was not a new historical phenomenon. Women have been working in factories since the early days of the first industrial revolution in the 1820s. Beginning with the young farm girls of New England who worked in the textile mills of Lowell, Massachusetts, manufacturers depended on women as a valuable and dependable source of labor. Continuing throughout the nineteenth century and into the twentieth century, women played an important part in the industrialization of America. Women worked in textile mills, sweatshops, and meatpacking plants. They were usually young, single, and helped support their families. ${ }^{2}$ Although married women did work outside of the home in the first half of the twentieth century, especially in textile mills in the South, it was unusual for married women to work. In 1920, only 23 percent of working women were married, a figure that increased to

1. Pauline Fisher, Oskaloosa, interview by Janet Clements, 4/18/1995, Iowa Labor History Oral Project, Iowa Federation of Labor, AFL-CIO, State Historical Society of Iowa (SHSI), Iowa City, Iowa (hereafter cited as ILHOP).

2. See Nan Enstad, Ladies of Labor, Girls of Adventure: Working Women, Popular Culture, and Labor Politics at the Turn of the Twentieth Century (New York, 1999); Susan A. Glenn, Daughters of the Shtetl: Life and Labor in the Immigrant Generation (Ithaca, NY, 1990); and Jacquelyn Dowd Hall et al., Like a Family: The Making of a Southern Cotton Mill World (Chapel Hill, NC, 1987). 
29 percent by 1930 . Most of these married working women were among the poorest in the United States, often African American, and they were sequestered in the lowest-paying jobs. Throughout the early twentieth century, it was uncommon for married women to work, and it was generally assumed that a young woman would quit her job once she got married.

That changed during World War II, when conditions combined to challenge the cultural and social assumptions that women were incapable of performing hard physical labor. Still, as Alice Kessler-Harris argues, the net gains from the war were negligible. Many women who worked during the war assumed that they would return home once the war was over, even though they may have wanted to continue to work. The iconic figure of Rosie the Riveter spurred women to fulfill their patriotic duty by taking up the rivet gun and fighting the war in the factory, but the country's leaders did not intend for Rosie to stay on the job once the war was over. She went home and focused on her family, fulfilling traditional homemaking roles. The war did not challenge assumptions about the primary gendered roles for women; the home remained the principal concern of the wife and mother. What was significant about the 1950s was how those gendered assumptions began to slowly erode, as married women with children began entering and reentering the paid workforce. In 1950, 29 percent of the workforce was female; by 1975, 40 percent was. The slow and steady transfer of women, especially married women with children, into the workforce provided a greater challenge to gender roles in the United States than even World War II did. ${ }^{3}$

Iowa certainly participated in this national trend. The number of employed women in Iowa increased from 170,350 in 1940 to 308,318 in 1960, an 80 percent increase over a 20-year period. Most of the growth occurred in the clerical and service sectors; clerical workers composed 37 percent of the female workforce in Iowa. Women not only worked in the traditional female job categories of clerical, domestic, and service work, but a significant number of women also worked in manufacturing, with 
40,304 women - 13 percent of all employed women - working in industry in 1960. What was especially remarkable about the number of women in manufacturing, however, was its rate of growth; the number of female factory workers increased 140 percent in just a twenty-year period. ${ }^{4}$

That growth coincided with an equally dramatic growth in industry in Iowa after 1945, as businesses relocated to the region as a result of capital mobility and decentralization. Nearly 900 new industrial firms opened business in Iowa from 1950 to 1965, and already prominent industries such as meatpacking and farm equipment manufacturing continued to expand production. That industrial growth opened up new job opportunities for men and women. ${ }^{5}$ Much of the growth was in electronics, where a significant number of women were hired for production. The combination of industrial growth with the national trend of women working outside of the home led to the rise in the number of women working in industry in Iowa after the World War II. A survey of those female factory workers indicates that a variety of manufacturing firms hired women, and a range of push and pull factors motivated women to work for those industrial firms.

Studies of the phenomenon of working women after World War II help explain why women worked outside of the home, but most of those studies focus on urban women in major cities while neglecting women working in small cities and towns scattered across the Midwest. ${ }^{6}$ The motivations of women working

4. U.S. Bureau of the Census, Iowa, 1960, Table 62, pp. 17-18.

5. See Coreen Derifield, "Earning Her Daily Bread: Women and Industrial Manufacturing in the Rural Midwest, 1950-1980" (Ph.D. diss., Purdue University, 2012), 14-43.

6. Alice Kessler-Harris, in Out to Work, provides an excellent overview of women working outside of the home throughout U.S. history. Dorothy Sue Cobble, The Other Women's Movement: Workplace Justice and Social Rights in Modern America (Princeton, NJ, 2004), discusses women's activism in the trade union movement after World War II. Nancy F. Gabin, Feminism in the Labor Movement: Women and the United Auto Workers, 1935-1975 (Ithaca, NY, 1990), analyzes female auto workers and their involvement in the UAW. Several excellent anthologies deal with women and work in the postwar period. See, for example, Carol Groneman and Mary Beth Norton, eds., "To Toil the Livelong Day": America's Women at Work, 1780-1980 (Ithaca, NY, 1987); Ruth Milkman, ed., Women, Work and Protest: A Century of U.S. Women's Labor History (Boston, 1985); 
in the rural Midwest have been understudied, and the group experiences of working-class women in Iowa provide an interesting alternative to those of women working in larger cities. Iowa women in meatpacking have received some scholarly attention, as a result of an increased interest in the United Packinghouse Workers of America (UPWA), which was a predominant union in the state. ${ }^{7}$ There has been little analysis, however, of women in the electronics industry, the state's largest employer of women. In the past few years, there has been a growing scholarly interest in Iowa women, but the growth in the number of women employed in manufacturing in the state has yet to be fully analyzed. ${ }^{8}$ Instead of a narrow focus on one industry or

Joanne Meyerowitz, ed., Not June Cleaver: Women and Gender in Postwar America, 1945-1960 (Philadelphia, 1994); and Dorothy Sue Cobble, ed., The Sex of Class: Women Transforming American Labor (Ithaca, NY, 2007). Nancy MacLean also has excellent sections on women in the workplace in Freedom Is Not Enough: The Opening of the American Workplace (Cambridge, MA, 2006). The section on RCA in Bloomington, Indiana, in Jefferson Cowie, Capital Moves: RCA's SeventyYear Quest for Cheap Labor (Ithaca, NY, 1999), provides a good comparison to Iowa women. Julia Kirk Blackwelder, Now Hiring: The Feminization of Work in the United States, 1900-1995 (College Station, TX, 1997), provides a careful analysis of some of the push factors. Ruth Milkman, Gender at Work: The Dynamics of Job Segregation by Sex during World War II (Urbana, IL, 1987), explains the recruitment process for women in industry.

7. See, for example, Dennis A. Deslippe, "'We Had an Awful Time with Our Women': Iowa's United Packinghouse Workers of America, 1945-75," Journal of Women's History 5 (1993), 10-32; and Bruce Fehn, " 'Chickens Come Home to Roost': Industrial Reorganization, Seniority, and Gender Conflict in the United Packinghouse Workers of America, 1956-1966," Labor History 34 (1993), 324-41.

8. Beginning with Louise Noun's important work on Iowa suffragists, Iowa women have received increased attention. See her Strong-Minded Women: The Emergence of the Woman-Suffrage Movement in Iowa (Ames, 1969); and More Strong-Minded Women: Iowa Feminists Tell Their Stories (Ames, 1992). Sharon E. Wood, The Freedom of the Streets: Work, Citizenship, and Sexuality in a Gilded Age City (Chapel Hill, NC, 2005), gives a wonderful account of women in Davenport. Dennis A. Deslippe, "Rights Not Roses": Unions and the Rise of Working Class Feminism, 1945-80 (Urbana, IL, 2000), provides a good overview of some working-class women in Iowa. In Cutting into the Meatpacking Line: Workers and Change in the Rural Midwest (Chapel Hill, NC, 1998), Deborah Fink writes about her experiences in a meatpacking plant in Perry during the 1990s and gives a good overview of women in meatpacking. For more on women in meatpacking in Iowa, see Shelton Stromquist and Marvin Bergman, eds., Unionizing the Jungles: Labor and Community in the Twentieth-Century Meatpacking Industry (Iowa City, 1997); Wilson J. Warren, Struggling with "Iowa's Pride": Labor Relations, Unionism, and Politics in the Rural Midwest Since 1877 (Iowa City, 2000); and Wilson J. Warren, Tied to the Great Packing Machine: The Midwest and Meat- 
union, this study provides a broad social survey that gives an overview of the many different industries in which women worked, and provides a fuller picture of the push and pull factors that influenced women in their decisions to work outside of the home.

AS MORE WOMEN began working outside of the home, public and social attitudes slowly shifted to accommodate the working woman. Although it was commonly believed that women with jobs would cause irreparable harm to the health and well-being of the American family, national leaders began to endorse the idea of women working. As the economy boomed after World War II, public leaders realized that the continued growth and stability of the economy required women to be not only consumers but also producers. Soon women began to provide the extra labor needed to fill low-level positions in manufacturing. The extra wages women earned allowed families to purchase new consumer products which in turn boosted the economy by sustaining the high rate of production. Julia Kirk Blackwelder argues that this need for working women caused a redefinition of motherhood and womanhood that allowed the public to accept women's transition from homemakers into workers. "Consumer desires," she explains, "propelled mothers to supplement the family income. . . . More and more mothers marched off to work during the 1950s, as economic forces - not for the first time-overcame the messages of popular culture." But this raised new questions about the cultural role of mothers: "How could conscientious motherhood coexist with the necessity for bringing women to new levels of participation and leadership in the economy?" Employers and bureaucrats, Blackwelder notes, "thought they had the answer in a redefinition of maternal obligation, a redefinition that included providing for as well as protecting children, a redefinition that ultimately prevailed." By the 1960s, Blackwelder argues, the definition of motherhood included providing for the family as well as giving nurturing care.

packing (Iowa City, 2007). Finally, Shelton Stromquist provides an excellent section on working women in Solidarity and Survival: An Oral History of Iowa Labor in the Twentieth Century (Iowa City, 1993). 


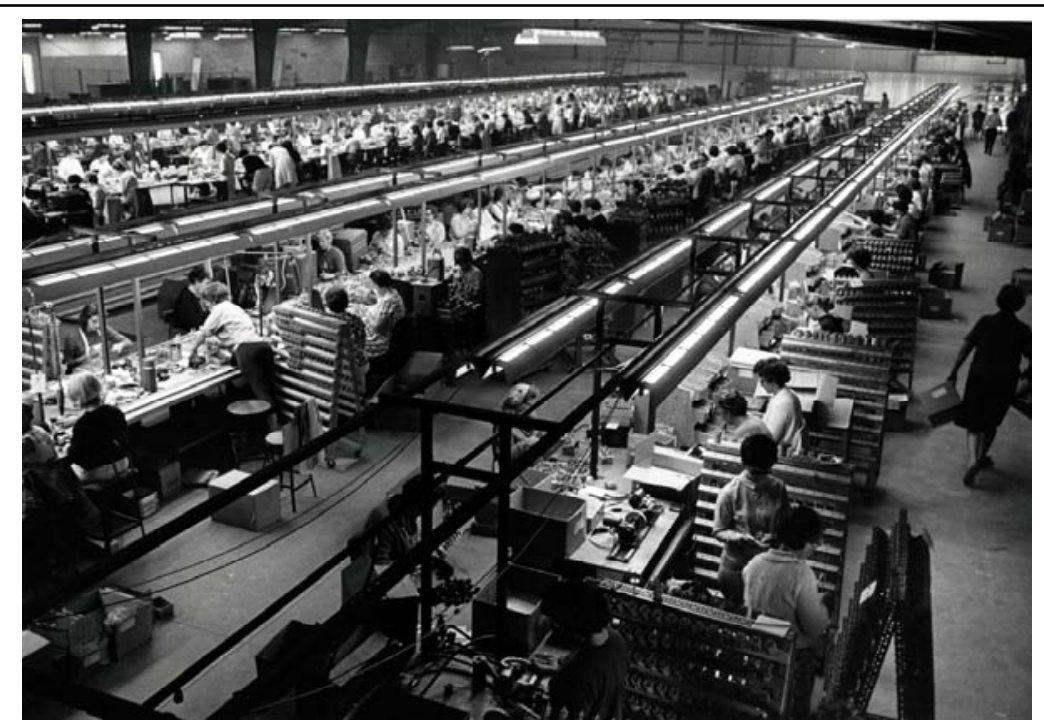

Rows of women work on production lines in the 1960s at Standard Kollsman Industries, which manufactured television tuners in Ottumwa. On January 8, 1967, the Des Moines Register reported on the firm's decision to locate in Ottumwa. "One of their key requirements was an abundant supply of female labor to man the tuner assembly lines. It just so happened that Ottumwa could offer more than enough of that type of labor. For years, the community has been almost exclusively a man's-work town, with the John Morrell and Co. slaughter plant and the John Deere Co. forage harvesting machinery factory employing over 4,500 men." Photo from State Historical Society of Iowa, Iowa City (SHSI-IC).

Alice Kessler Harris also notes this change, adding that families began turning to women's wage work as a way to handle the family economy, rather than depending on children's wages or a wife's penny-pinching, belt-tightening household budgeting. She argues that the decades after the war were "marked by the dawning recognition within families that women's functions of cushioning depression and fighting inflation ... might be more effectively handled by wage-earning." 9

In Iowa, many prominent leaders took notice of the national and statewide trend of women going to work and eventually endorsed the transformation as beneficial to the state. Governor

9. Blackwelder, Now Hiring, 148, 153; Kessler-Harris, Out to Work, 302. 
Harold Hughes created the first Governor's Commission on the Status of Women in 1964 and assigned it the task of assessing the changes occurring within the state's female population. The governor charged the commission to realize the urgency of understanding this new trend of women working, for "the increased participation of women in aspects of Iowa society has changed so rapidly that our state's laws and customs have lagged in fully accepting and adjusting to the changing activities of women. A few generations ago the working woman was rare and not fully accepted. Today one-third of Iowa's women are employed." 10

The Governor's Commission analyzed the increasing number of women working, noting that those working outside the home had increased by 70 percent since 1940 . Of the 318,117 working women in 1964, 45,000 were heads of household and 28 percent of all married women were employed. The commission ultimately concluded that the high rate of female employment was good for the state's economy, so it encouraged employers to continue hiring women. It distributed information to employers "stressing the positive aspects of employing women, such as, the favorable absentee rate of women who have re-entered the labor market after their child-bearing years." 11 According to the U.S. Census, the number of women working in Iowa increased 20 percent from 1950 to 1960 (see table 1). The greatest increase was among rural, non-farm women, whose level of employment increased 25 percent over the ten-year period. More urban women worked outside of the home than rural women, but both categories increased 20 percent from 1950 to 1960.

The governor's office was not the only state agency to take notice of this change; the Iowa Development Commission also reported on the increase in the number of employed women. It identified approximately 190,000 women working in the state, 23 percent of whom were employed in manufacturing. Women even outnumbered men in seven different fields of employment,

10. Governor Harold Hughes to the Members of the Governor's Commission on the Status of Women, 10/11/1963, box 1, Governor Ray's Commission on the Status of Women (Iowa) Records, Iowa Women's Archives, University of Iowa Libraries, Iowa City, Iowa (hereafter cited as IWA).

11. “Employment Practices Concerning Women," box 1, Governor Ray's Commission on the Status of Women (Iowa) Records. 
TABLE 1

IOWA WOMEN IN THE LABOR FORCE, 1950 AND 1960

\begin{tabular}{lcccc}
\hline & $\begin{array}{c}\text { Women } \\
\text { Working } \\
1950\end{array}$ & $\begin{array}{c}\text { Women } \\
\text { Working } \\
1960\end{array}$ & $\begin{array}{c}\text { Women } \\
\text { Not Working } \\
1950\end{array}$ & $\begin{array}{c}\text { Women } \\
\text { Not Working } \\
1960\end{array}$ \\
\hline State & 249,524 & 318,117 & 735,645 & 680,478 \\
Urban & 165,003 & 208,842 & 339,083 & 344,244 \\
Rural Non-Farm & 51,192 & 68,327 & 177,642 & 165,029 \\
Rural Farm & 32,929 & 40,928 & 218,920 & 171,205 \\
\hline
\end{tabular}

SOURCE: U.S. Bureau of the Census, Iowa, 1950 and 1960.

most of which were traditional pink-collar jobs such as communications (54 percent women), retail trade (70 percent), and department stores (73 percent). Table 2 illustrates the increasing number of women employed from 1940 to 1960 and the economic sectors in which they worked. Most women worked in clerical and sales; in 1960 clerical represented 70 percent of all the women working. Women also worked in domestic service, agriculture, and manufacturing. ${ }^{12}$

While manufacturing claimed only 10 percent of the total number of women working, its share increased significantly during this period. Women in manufacturing worked predominantly in electronics, meatpacking, machinery, and rubber. Although many mass-production industries, such as the farm equipment and grain-milling industries, continued to deny employment to women, there was more opportunity for women in machinery (which included electronics) and durable and non-durable goods. ${ }^{13}$ Table 3 illustrates the different types of manufacturing that employed women. Food production and machinery saw the greatest growth in the 20-year period.

FOUR MAJOR MOTIVATING FACTORS pushed Iowa women into the paid workforce after 1950: a prevalent culture of hard work, previous work experience, a desire for extra in-

12. "Women Outnumber Men in 7 Major Industries," Iowa Development Bulletin, 11/28/1952, SHSI.

13. U.S. Bureau of the Census, 1940, Table 18; 1950, Tables 28, 31; 1960, Table 57. 
TABLE 2

WOMEN WORKING IN IOWA

\begin{tabular}{lccr}
\hline & 1940 & 1950 & \multicolumn{1}{c}{1960} \\
\hline Professional & 31,823 & 36,539 & 44,900 \\
Clerical/Sales & 51,053 & 88,453 & 114,194 \\
Domestic Service & 29,694 & 16,091 & 20,961 \\
Manufacturing & 16,530 & 30,833 & 30,636 \\
Service & 23,508 & 37,160 & 55,766 \\
Agriculture & 5,398 & 19,512 & 4,690 \\
\hline Total Working & 170,350 & 244,745 & 308,318 \\
\hline
\end{tabular}

SOURCE: U.S. Bureau of the Census, 1940, Table 18; 1950, Table 28 and 31; 1960, Table 57.

come to cushion the family economy, and, most important, economic need. Iowa women had an ingrained cultural appreciation for hard work accompanied by a deep sense of duty to the family. These notions of duty and hard work were embedded in their regional identity as midwesterners, something that was appreciated because it was passed on through generations.

Parents in Iowa, whether on the farm or in town, raised their children to value a hard day's work and trained them how to work, whether inside the home, on the farm, or in the workplace. Edith Arendt, a lifetime worker at Collins Radio in Cedar Rapids, remembered how her father taught her the importance of hard work. "My father thought that hard work was good for everyone. And taught me to do it when there was any chore to be done or any repair work to go ahead and do it and try to succeed." Doris Peick, who also worked at Collins Radio, recalled how she had to go to work in a bakery when she was just 14 years old to help her mother after her father died of lung cancer. She and her mother left the farm and moved to Cedar Rapids, where Peick got a job greasing pan loaves. She remarked, "Thank God I was a large, economical size farm girl; you just really had to do the work of an adult, and I assumed that responsibility pretty efficiently, because I didn't get fired and I worked all the hours that I could and saved every cent I could for my school clothes." Women like Peick and Arendt brought this understanding of hard work with them when they started their own families, and they, in turn, taught their own children 
TABLE 3

IOWA WOMEN IN MANUFACTURING

\begin{tabular}{lccr}
\hline Year & 1940 & 1950 & 1960 \\
\hline Food and Kindred Products & 5,437 & 9,509 & 10,995 \\
Machinery & 1,074 & 5,447 & 10,385 \\
Durable Goods & 3,157 & 5,224 & 7,906 \\
Non-Durable Goods & 3,906 & 6,952 & 7,286 \\
Apparel & 2,159 & 2,735 & 3,169 \\
Other & 831 & 1,022 & 563 \\
\hline Total Manufacturing & 16,564 & 30,889 & 40,304 \\
\hline
\end{tabular}

SOURCE: U.S. Bureau of the Census, Iowa, 1960, Table 62.

the importance of hard work. So when these women found themselves in need of additional cash, they were willing and able to find a job to provide for the family. ${ }^{14}$

When women began working full time, they often had some previous work experience that helped ease them into a 40-hour work week. Women accumulated experience by working during World War II or immediately after high school. Many young women worked after high school to save for their future marriages or to support themselves until they got married. Most of them worked as waitresses or clerks in department stores. Artis Hatland England, for example, graduated from high school in 1946 in Emmet County, Iowa, and worked as a waitress to save money for her marriage. But, like many other women, she quit shortly after starting a family. Some women gained work experience during the war, which helped them find employment once the war was over. Mary Speer, a welder in the shipyards in Portland, Oregon, commented, "It was hard work, but I really enjoyed it. But I guess I got kind of homesick to come back home." She returned to Iowa and applied at the new Firestone Tire plant in Des Moines, remembering that she "applied for a job one morning and went to work that night on the eleven to seven shift." 15

14. Doris Peick, Cedar Rapids, interview by Merle Davis, 8/24/1982, ILHOP; Edith Arendt, Cedar Rapids, interview by Greg Zieren, 10/31/1979, ILHOP.

15. Mary Speer, Des Moines, interview by Greg Zieren, 2/16/1980, ILHOP; Artis Hatland England, Johnson County, Autobiographical Sketches of Rural Women, IWA. 
A desire for the extra comforts in life also pushed women into the workforce. After years of depression and war, families in Iowa and across the nation longed for a return to normality and wanted to provide their children with the extra things they went without during the Depression. Women wanted a better lifestyle for their families, free from the worry over economic hardships they had faced. Josephine Gerard went to work at the Amana Refrigeration Company so she and her husband could afford to buy their six children the extra things she did not have when she was growing up during the Depression. She remarked,

Laurel, my husband, was not a bit happy to think that I wanted to go to work, but I thought of the money that we could use. I was raised on not enough clothes, not enough food and I swore to God that my kids were gonna have something. And Laurel worked, Laurel has never been a man that hasn't worked, but when you got kids and kids, it takes a lot. And I knew that he could support us for basic things, but my kids would never be able to do or get anything extra, you know, if I didn't go to work and that's the reason I went to work. ${ }^{16}$

Some women, like Eunice Evans, who also worked at Amana, wanted to be able to afford to give their children better food. "I decided I wanted an adequate diet for my children. I had one boy that had polio and I always felt it was because he didn't have the meat and fresh fruits that he needed and with my salary we could afford to buy them." 17 Fern Klopp decided to seek employment so that she could send her daughter to nursing school. She applied at Turner Microphone in Cedar Rapids, recalling, "We only lived two blocks from the plant so I decided that maybe I could help out until she got through nurse's training." 18

But the most important factor pushing women into the workforce was economic need. Women's economic need developed from a variety of factors: their husbands became disabled, they got divorced, or their families were no longer able to survive on a single income. Some women had husbands who became sick or handicapped, so they sought work to substitute for

16. Josephine Gerard, Amana, interview by Janet Clements, 1/12/1982, ILHOP.

17. Eunice Evans, Amana, interview by Janet Clements, 3/6/1995, ILHOP.

18. Fern Klopp, Cedar Rapids, interview by Greg Zieren, 9/12/1980, ILHOP. 
their husbands' lost incomes. Joyce Burrows, whose husband lost a finger while working at John Deere, went to work at Flexsteel in Dubuque sewing cushions for couches and chairs. Helen Erdmann went to work at Black's Department Store in Waterloo because her husband became ill. "My husband worked at John Deere's," she explained. "He'd had a serious operation in March of 1956 and he was not convalescing as fast as he could have, and at that time the insurance benefits weren't like they are now. So we thought we needed another income."19

Some women became heads of households either because their husbands died or, more commonly, their marriages ended. Edith Arendt farmed with her husband for a few years. After he died, she sold the farm and moved to Cedar Rapids to work at Collins Radio. Marlene Kruger had a clear understanding of why she had to go to work: "In 1966 my first husband walked out on me and left me with three small children and that threw me into the job market. I had to support the children and I got a job at Waterloo Industries through a friend." Jeannette Haymond had a similar story. She married young and had two children when her husband left her. ${ }^{20}$

Other women worked because their families needed two incomes. Bev Clinton did not work the first two or three years of her marriage, but, as she commented, "It had become part of the household to have two incomes." She went to work at Square D in Cedar Rapids, an electronics factory. Susan Rhum worked at the ammunition plant in Burlington in 1963 because it was difficult to support her family on only one paycheck. Carol Carter worked at the Champion spark plug plant in Burlington because it paid well and she was "anxious to make a good living for my family." 21

19. Joyce Burrows, Dubuque, interview by Dan Holub, 5/21/1991, ILHOP; Helen Erdmann, Waterloo, interview by Merle Davis, 6/2/1982, ILHOP.

20. Edith Arendt interview; Marlene Kruger, interview by Dan Holub, 6/27/ 1991, ILHOP; Jeanette Haymond, Cedar Rapids, interview by Paul Kelso, 11/9/ 1977, ILHOP.

21. Bev Clinton, Cedar Rapids, interview by Dan Holub, 8/6/1991, ILHOP; Susan Rhum, Burlington, interview by Merle Davis, 2/14/1983, ILHOP; Carol Carter, Burlington, interview by Merle Davis, 1/12/1982, ILHOP. 


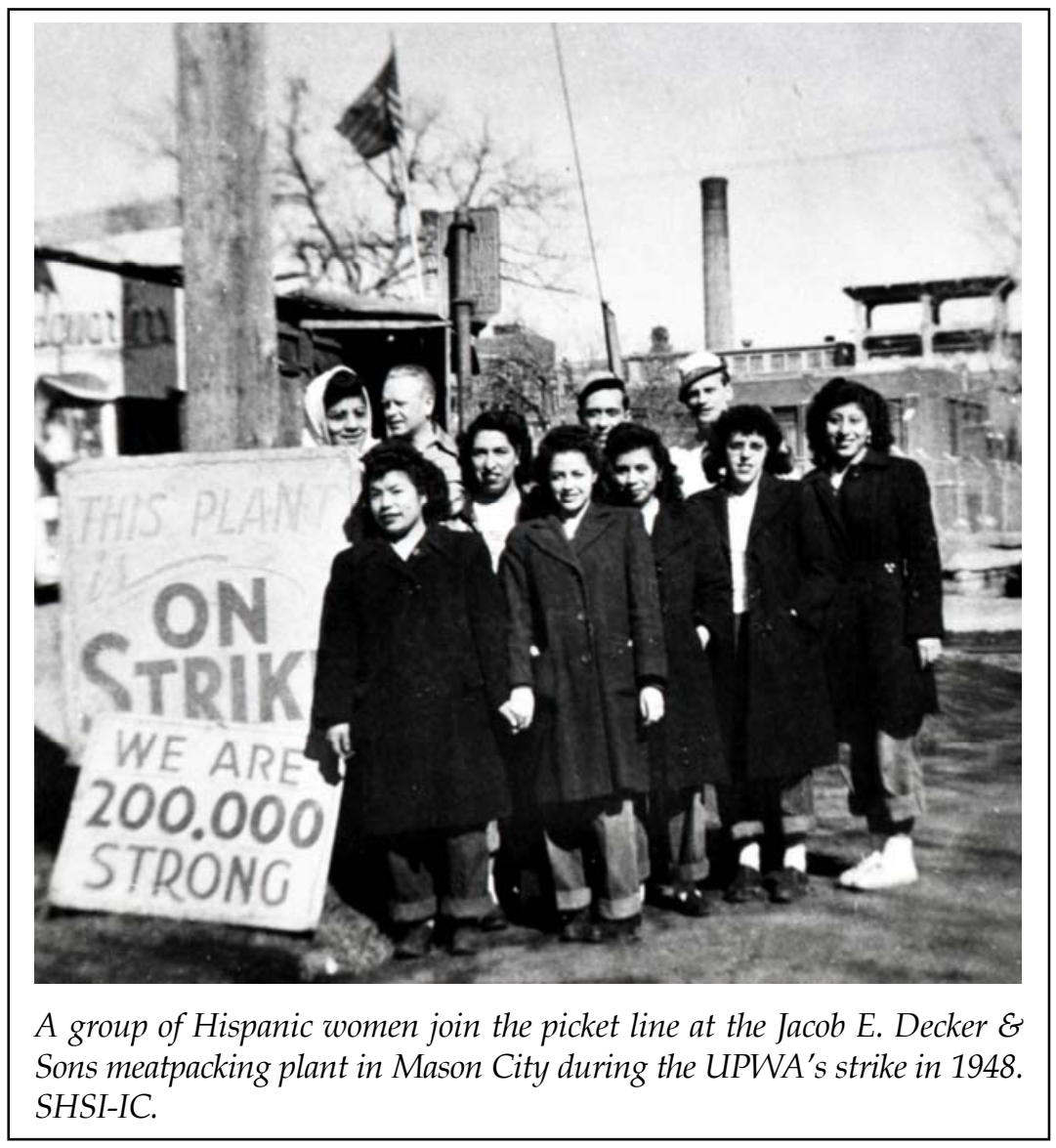

Minority women especially struggled to survive economically with the limited opportunities they had for work because of racial discrimination. Even though the minority population of the state was small, lingering around 5 percent for the 20-year period, the experiences of minority women echoed those of white women. Two Latina sisters, Maria Mercedes Aguilera and Delores Garcia, grew up very poor in a large family in Muscatine. Both of them had to search for work at a young age. Migrating between Chicago and the Quad Cities searching for work, both eventually landed in Davenport working in manufacturing jobs. ${ }^{22}$

22. Maria Mercedes Aguilera, interview by Janet Weaver, 9/22/2005, Mujeres Latinas Oral History Project, IWA. 
African American women, who suffered the double discrimination of sexism and racism, found it difficult to secure promising jobs in industrial manufacturing. Most firms were reluctant to hire black women; some absolutely refused to do so. The meatpacking industry was a case in point. Not until a handful of courageous women brought the attention of the federal government to the discrimination within the industry did it begin hiring African American women. ${ }^{23}$

Rural women faced special economic challenges during the 1950s that drove them off the farm to seek work. Rural women were accustomed to providing for their families, as they took charge of dairy cows and chickens, selling milk, butter, and eggs to a local market. Those endeavors provided women with cash to purchase additional food items they could not raise or grow themselves; they also used the money to purchase supplies such as shoes, clothing, and household items. That income eased the family budget and provided the overworked farm wife with some extra padding to purchase things she needed. After World War II, however, the restructuring of the dairy and poultry industries rendered those independent economic endeavors obsolete. As the poultry industry changed from the decentralized production in women's backyards into a vertically integrated farming operation, women's small flocks could not keep up. Large-scale poultry operations soon took over the industry. Women also lost the small dairy income they had maintained by selling milk and butter. As Jane Adams notes in her study of Union County, Illinois, "The loss of markets for these agricultural products placed enormous strains on household budgets, since women's sales had virtually provisioned the family." 24

Farm prices as a whole also failed after the war, as markets became unstable. Those who operated only small farms, and those who rented, found it increasingly difficult to stay afloat. As wartime price supports were removed, the market became

23. Bruce Fehn, "African-American Women and the Struggle for Equality in the Meatpacking Industry, 1940-1960," Journal of Women's History 10 (1998), 45-69.

24. Deborah Fink, Open Country Iowa: Rural Women, Tradition and Change (Albany, NY, 1986), 190; Jane Adams, The Transformation of Rural Life: Southern Illinois, 1890-1990 (Chapel Hill, NC, 1994). 
more variable, causing general instability of prices. Either the husband or the wife needed to go in search of work to ensure the economic stability of the farm. As Luella Zmolek noted, "Somebody had to work. We had to have more income, and so I decided, well, I guess I would go to work. That's just the way it was. I think, [at] first I wondered how I was going to go to work when I had six kids to take care of, but, on the other hand, I thought, Well, I guess I'll try." Ilo Rhines also decided to work, and she appreciated her job at the postal service. She noted, "What saved us on the farm, what kept us so we could stay there, was an opportunity that I had to join the postal service. And you know, it was an above average wage. But that was one of the reasons that we were able to [stay] - it wasn't because farm prices got so darn great." 25

Beverly Everett, a prominent speaker in farm circles in Iowa during the 1960s, encouraged rural women to think about additional economic opportunities to support the farm. She testified, "Both my husband and I feel that, should weather or health fail, the other should be equipped to step in and provide an income." After her four children were in school, she decided to go back to college and gain a teaching certificate. She argued, "Whether I take a job or not, we are more ready as a family to meet a financial crisis." Everett also noted in many of her speeches that women were increasingly working off the farm in a variety of different ways to earn income. She described the various activities of her farm neighbors: Hazel worked as a nurse; Barb owned a shop in town; Mabel taught second grade; Faye worked at a bookstore; and Lucille cooked in the school lunchroom. ${ }^{26}$

Although most women who sought jobs outside of the home or the farm worked in clerical or sales jobs or professions such as nursing or teaching, a significant number of women also worked in manufacturing. This is a curious factor when taking into account the rural or small-town background of many Iowa

25. Luella Zmolek, interview by Doris Malkmus, 9/10/2001, Voices from the Land: Oral History Project in Iowa, Special Collections Department, Iowa State University, and IWA; Ilo Rhines, interview by Doris Malkmus, 10/26/2001, Voices from the Land.

26. Beverly Everett, “The Family Farm Has a Future If . .." Farm Journal, April 1963, box 6, IWA. 
women. As Eunice Evans, a rural woman who worked at the Amana Refrigeration Company, recalled, "I think I probably had a lot of dreams like most kids, but nothing serious. It certainly didn't involve working in a factory." Both rural and urban women chose to work in manufacturing, but the number of urban women was significantly larger than the number of rural women. In 1960 approximately 300,000 women were working in the state, 66,000 of whom were rural non-farm women and 40,000 of whom were rural farm women. Of the rural farm women, 17 percent chose clerical work, with 13 percent in the medical field, 8 percent in teaching, and just 6 percent in manufacturing. The small percentage of rural women reported as working in manufacturing failed to reflect the movement of rural women off the farm and into towns. A higher number of women working in manufacturing had rural backgrounds than it appears from the census. For example, out of the 86 women who participated in the Iowa Labor History Oral Project, 26 (30 percent) came from a farm background, but only 4 of them continued to live on a farm. These working women with a rural background crossed a rural/urban divide to forge new identities that combined rural experiences with urban ones, dissolving them to form a unique working-class consciousness based on a shared regional identity. ${ }^{27}$

OF THE PATHS available for Iowa women, why would they choose work in manufacturing? For one, there were not a lot of options for women to choose from, as Esther Witmer commented. "You know our options weren't as numerous as they are now. You could be a secretary or you could be a teacher or you could be a hired girl." Sally Putman echoed this lament. "I can remember the opportunities for young women were you could either be a beautician or a nurse or a secretary. Well, I knew that a beautician and a nurse was out for me. I just was not interested in that kind of thing. And so I took secretarial courses in high school." Young women with the foresight or the economic re-

27. 1960 U.S. Census; Martha Linn, interview by Doris Malkmus, 9/18/2001, Voices from the Land; Eunice Evans, Amana, interview by Janet Clements, 3/6/1995, ILHOP. 
TABLE 4

DISTRIBUTION OF WORKING WOMEN IN IOWA BY INDUSTRY AMONG SAMPLE FROM IOWA LABOR HISTORY ORAL PROJECT

\begin{tabular}{lrr}
\hline Industry & N & $\%$ \\
\hline Electronics & 25 & 30 \\
Meatpacking & 23 & 26 \\
Telephone Operator & 9 & 10 \\
Apparel & 6 & 7 \\
State Jobs & 5 & 6 \\
Misc. Industries & 5 & 6 \\
Office Jobs & 5 & 6 \\
Rubber & 4 & 5 \\
Food Preparation & 2 & 2 \\
Unemployed/Auxiliary & 2 & 2 \\
\hline
\end{tabular}

SOURCE: Iowa Labor History Oral Project, Iowa Federation of Labor, AFL-CIO, State Historical Society of Iowa, Iowa City, Iowa.

sources could and did receive training to become nurses, teachers, or secretaries. ${ }^{28}$

Industrial wage work provided a prime opportunity for women with little education and skill to earn an income. Martha Linn, a young woman in southwestern Iowa, had high hopes of attending college, but was disappointed that neither she nor her family could afford it. She noted that at least "there was a Union Carbide factory in Red Oak, and they paid good wages, and so I went over there to work instead." 29 Women worked in these jobs for the simple reason that they were there, they hired women, and they paid better than clerical or service sector jobs.

With the significant increase in manufacturing firms in Iowa in the 1950s and 1960s, especially in those trades that hired women, jobs in industry became even more readily available to Iowa women. Table 4 shows the variety of jobs held by 86 women who recorded oral histories with the Iowa Labor History Oral Project in the 1980s and 1990s. Most women worked in electronics and meatpacking, but a fair number of women

28. Esther Witmer, interview by Doris Malkmus, 4/3/2001, Voices from the Land; Sally Putman, interview by Doris Malkmus, 10/27/2000, Voices from the Land.

29. Martha Linn, interview by Doris Malkmus, 9/18/2001, Voices from the Land. 
also worked in other industries such as apparel and rubber. ${ }^{30}$ Those particular industries created spaces within the factory for women's work and provided women with good-paying jobs.

Apparel was a traditional "female" industry, and Iowa had a strong tradition of apparel industries, especially in Muscatine, which was famous nationally for its button industry. By 1910, there were 43 button factories in Muscatine employing approximately 2,500 workers-about two-thirds of Muscatine's workforce. The button industry was the fourth-largest employer of female workers in the state. Women worked as machine operators drilling holes, pressing patterns, and polishing buttons. ${ }^{31}$

Besides button making, small apparel factories peppered the state in small towns and cities, employing anywhere from 50 to 300 women. Apparel factories produced everything from overalls to flannel shirts to hunting garments. After World War II, apparel manufacturing continued to grow as new factories sprang up across the state. Some manufacturers chose new locations based on the availability of a female labor pool. In her study of rural women in Iowa, Deborah Fink identifies several farm women who worked in apparel factories. She claims that "these factories were specifically planted to tap the labor of rural women." As one manager confided to her, "the factory's location was chosen because the owners understood that rural women needed jobs." Such factories usually opened in the 1950s and employed about 100 female workers. They were typically the size of a large gymnasium, with sewing stations scattered throughout the plant with cutters transporting the unassembled garments to the different assembly stations. The few men who worked at these factories were assigned the heavier work such as cutting and transporting the material. ${ }^{32}$

Typical of these factories was the Hinson Manufacturing Company, a family-owned business in Waterloo that employed about 300 women. Hinson produced a variety of products, from

30. "Women Outnumber Men in Seven Major Industries," Iowa Development Bulletin, 11/28/1952, SHSI.

31. Kate Rousmaniere, "The Muscatine Button Workers' Strike of 1911-12: An Iowa Community in Conflict," Annals of Iowa 46 (1982), 243-62.

32. Fink, Open Country Iowa, 190-93; Florence Paul, Oskaloosa, interview by Merle Davis, 4/5/1982, ILHOP. 
textile automotive accessories and hunting garments to sportswear and tractor accessories. Wilma Riley, who worked at Hinson after the war, ran a sewing machine, and Ilene Christianson made seat covers for automobiles. Like other apparel factories, Hinson had a handful of men who worked the heavier jobs, but women filled most of the work stations. ${ }^{33}$

Another garment factory, the Clinton Garment Company in Clinton, assembled women's dresses for Sears under the labels Tony Todd and Vicki Block. The factory employed approximately 250 women and 20 men. The women did all of the sewing, and many of the sewing stations, such as collars, zig zag, and hook and eyes, took a significant amount of skill. Women usually worked under a piecework system that paid them for the number of garments they completed rather than an hourly rate. The women enjoyed working under piecework because it enabled them to make a higher rate and more money. The women at Clinton Garment cultivated a family-like atmosphere in their workplace as they worked side by side for many years. The women were typically of similar age, married, and had children. Irene Vaughn, a worker at Clinton Garment, remarked that she "enjoyed it, everybody enjoyed it. It was just like a club. Everybody liked each other and you could talk as you worked. If you wanted to work hard, you made really good money." The apparel industry was a good opportunity for working women, offering decent wages, a clean working environment, and fellowship with other female workers. ${ }^{34}$

Meatpacking was another important industry in the state that had a long tradition of hiring women. Nationally, meatpackers began hiring female laborers as early as the 1880s, putting them in canning or in by-product departments to produce such things as lard, sausage, and canned meat. The greatest increase in women's employment occurred in the 1890s. By 1904

33. Waterloo, Industry, vertical file, SHSI; Wilma Riley, Waterloo, interview by Merle Davis, 7/22/1980, ILHOP; Ilene Christianson, Waterloo, interview by Merle Davis, 6/11/1981, ILHOP.

34. "Where Industry and Agriculture Meet," Clinton, Iowa, vertical files, SHSI; Viola Juehring, Clinton, interview by Merle Davis, 7/8/1982, ILHOP; Alice Oltmanns, Clinton, interview by Merle Davis, 6/28/1982, ILHOP; Irene Vaughn, Clinton, interview by Dan Holub, 6/15/1991, ILHOP. 


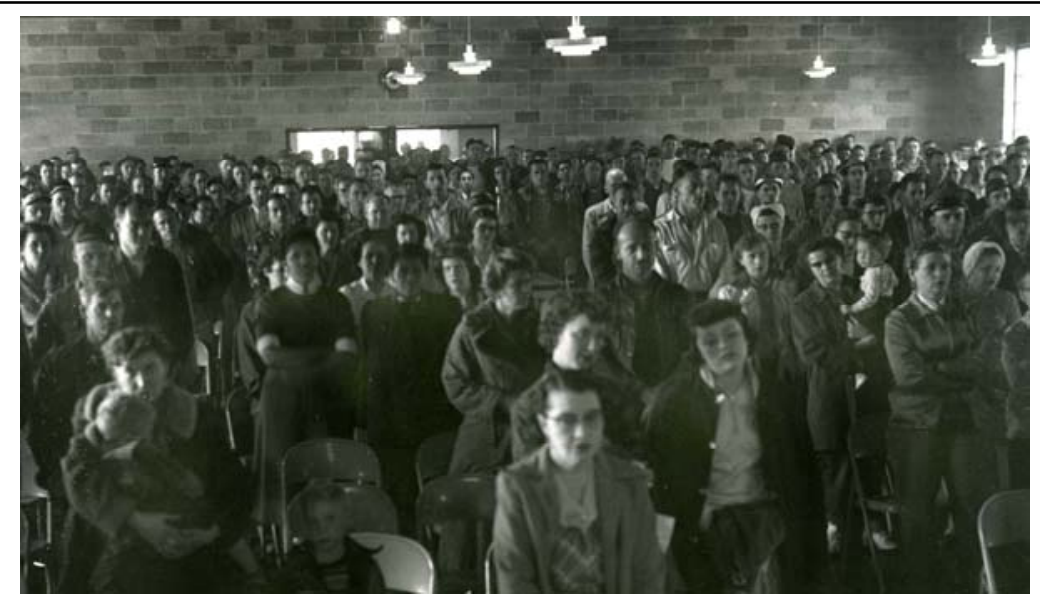

Women, many with small children in tow, are heavily represented during a UPWA strike vote in Waterloo, ca. 1954. SHSI-IC.

nearly 2,000 women worked in Chicago's meatpacking industry. Those women worked in the lower-paid and unskilled jobs that took very little training. As historian James Barrett notes, the "extreme division of labor and the mechanization of some operations diluted the degree of skill required for most jobs, reducing them to tasks that women were deemed capable of performing." Those jobs typically included filling cans, trimming meat, making sausage casings, packing lard and butter, and canning chipped beef. The higher-paid jobs were reserved for men, because men were considered the family breadwinners. ${ }^{35}$

Once it became customary for women to work certain jobs, those jobs became known collectively as women's work. In that way, women's jobs became institutionalized within the meatpacking industry and were known as female jobs simply because women had always worked them. Sociologist Ruth Milkman terms this process structural inertia, explaining that the beginning, formative period of any industry or organization is crucial "because an industry's pattern of employment by sex, once established, quickly gains all the weight of tradition and becomes extraordinarily inflexible. Employers show surpris-

35. James R. Barrett, Work and Community in the Jungle: Chicago's Packinghouse Workers, 1894-1922 (Urbana, IL, 1987), 51. 
ingly little interest in tampering with it, even to enhance profitability. Workers, too-both male and female-tend to accept the sexual division of labor, once established, as "natural.'" 36 In the meatpacking industry, once certain jobs became known as women's work, it became extremely difficult for women to move out of those jobs and into higher-paying departments. In this way, the sexual division of labor worked as a double-edged sword: in one sense, it guaranteed that women would always have jobs in the plant, but it also kept them in the lowest-paid positions with little chance of moving to a higher-paying job. ${ }^{37}$

The meatpacking industry in Iowa offered good opportunities for women seeking work. Even though women earned lower wages than male employees, work in the packing plants still paid more than most employment available to women. Some of the major employers in the state were Rath Packing in Waterloo, Wilson Foods in Cedar Rapids, John Morrell in Ottumwa, Hormel in Fort Dodge, and Armour in Mason City. Those plants were located in medium-sized cities and were able to employ women from a widespread area of 30 to 40 miles surrounding the plant. For example, the John Morrell plant in Ottumwa employed men and women from the town and the surrounding area. According to historian Wilson Warren, by 1950, 15 percent of the 3,500 in Morrell's workforce were women. ${ }^{38}$

Once women obtained jobs, they worked in lower-paid, lower-skilled positions throughout a plant, usually concentrated in bacon, sausage, or canning departments. Sometimes women worked as trimmers or in cured meat departments, but they were not allowed to work on the "heavy" jobs such as those in the kill and cut departments. In the canning department women cleaned, packaged, and labeled canning products. Work in the sausage department involved stuffing sausages and making lunch meat products, such as hot dogs or wieners. The bacon department contained several conveyor lines; at each conveyor,

36. Milkman, Gender at Work, 8.

37. Rick Halpern, Down on the Killing Floor: Black and White Workers in Chicago's Packinghouses, 1904-54 (Urbana, IL, 1997), 16; Roger Horowitz, "Negro and White, Unite and Fight!": A Social History of Industrial Unionism in Meatpacking, 1930-90 (Urbana, IL, 1997), 163.

38. Warren, Struggling with "Iowa's Pride," 69, 115. 


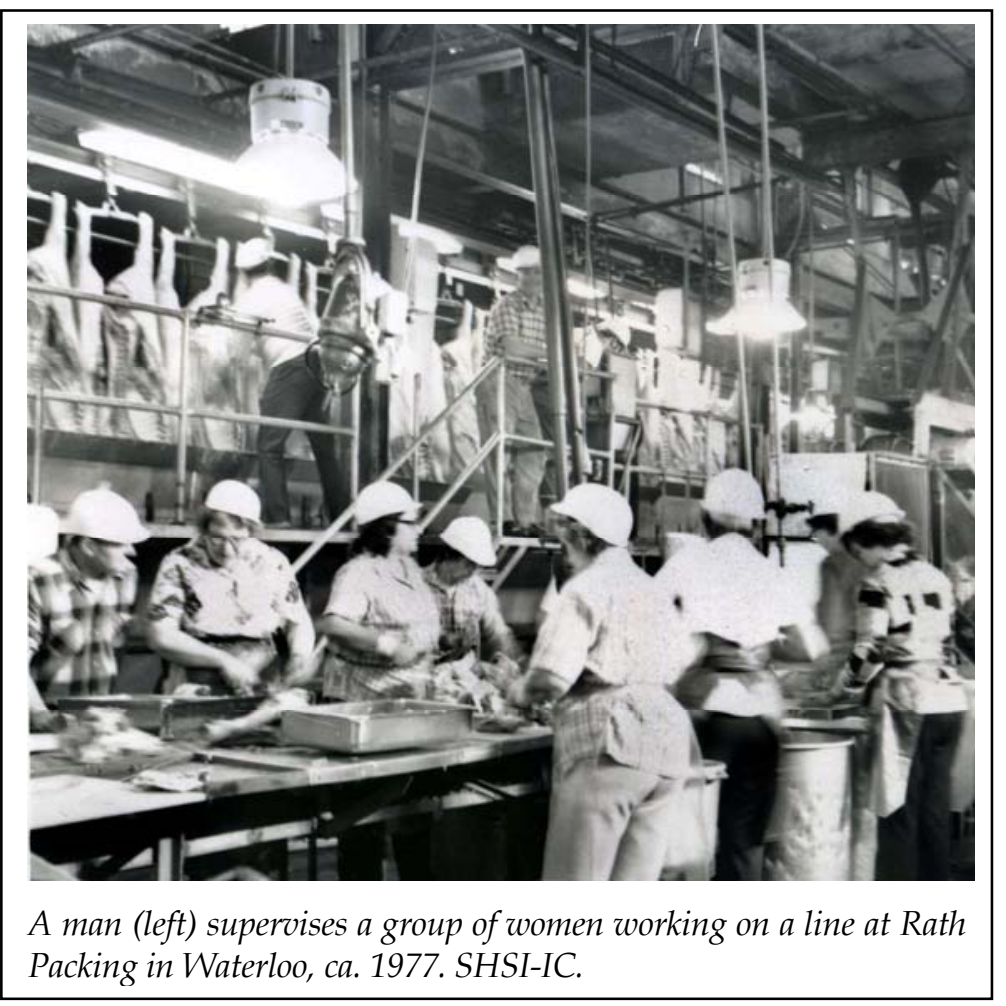

one person, usually a male, stood at the head of the belt slicing the bacon into strips. The women lined the belt layering the bacon; at the end, a woman weighed the layered bacon to ensure that there was a pound. The women at the very end of the line were in charge of packaging and boxing. Each conveyor line involved approximately 10 women, with 10 to 20 lines in the bacon department, creating about 100 to 200 jobs for women.

These jobs in a meatpacking plant were not always easy, or even clean. Velma Wetzel worked on a chitterling crew unraveling large intestines from a butchered hog and flushing out the leftover fecal matter. Wetzel would then store the intestines so the company could sell them as chitterlings. It was a very dirty job, and, according to Wetzel, if you weren't careful, you could be completely covered in fecal matter by the end of the day. De- 
spite the dirty, smelly conditions of work in packing plants, it did enable thousands of Iowa women to support their families. ${ }^{39}$

Large-scale poultry production also began after World War II. Poultry producers opened small processing plants in towns and rural areas across the country, especially in Iowa. Women had been instrumental in poultry production during the first half of the twentieth century, so poultry processors continued the tradition of female employment. Deborah Fink, who emphasizes the importance of poultry processing in a rural community, discusses a small poultry plant that hired women to butcher, clean, cut, and pack chickens, turkeys, ducks, and geese. A poultry plant in a small town near Ottumwa employed approximately 350 women, including Darlene Croft, who packed and canned boneless chicken. ${ }^{40}$

The electronics industry was perhaps the largest employer of women in the state, with nearly 2,000 women working in electrical manufacturing in 1950. The industry, which had employed men and women almost from the beginning of its history, began to grow in the 1880s and 1890s, when inventors found new uses for electricity. Men who had considerable knowledge of the science and technology of electricity were the first employees of the burgeoning industry, but as the industry grew and developed the basis for mass production, industrialists began to break down the modes of production into basic, repetitious jobs, a process known as deskilling. Because mass production work in electronics industries was not as physically demanding as other types of assembly work, industrial leaders viewed women as good candidates for this semi-skilled labor. Electrical production involved tedious repetition dealing with small intricate parts, and industrialists believed that women's small, nimble fingers, accustomed to long hours of sewing, were perfect for the new work. As historian Ronald Schatz notes, "The jobs which women had traditionally held in electrical factories required speed, attention to detail,

39. Violet Boharty, Ottumwa, interview by Merle Davis, 9/15/1981, ILHOP; Lucille Bremer, Waterloo, interview by Merle Davis, 6/2/1982, ILHOP; Velma Wetzel, Waterloo, interview by Greg Zieren, 10/12/1979, ILHOP.

40. Darlene Croft, Estherville, interview by Merle Davis, 11/11/1982, ILHOP; Fink, Open Country Iowa, 192. 


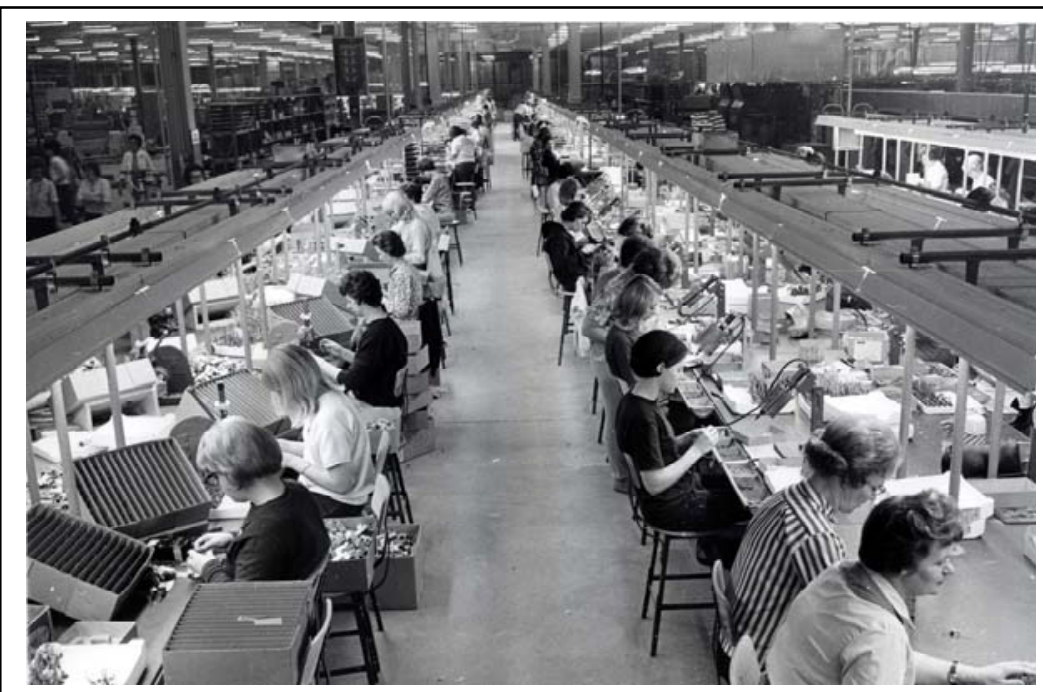

Women work on assembly lines at Wincharger Corporation, a manufacturer of small wind electric generators in Sioux City, ca. 1960. SHSI-IC.

nimble fingers, and intense concentration-qualities which managers summed up in the condescending term 'dexterity.'" And as in meatpacking, once women began working these jobs and could perform them with a high degree of proficiency, the jobs became known as women's work. Electronics companies identified most of the work in their factories as "light" work, and it became synonymous with women's work, a process Ruth Milkman refers to as sex-typing. Milkman argues that the nature of sex-typing was highly variable; in each plant what was considered men's or women's work depended on the plant itself. As a rule, most jobs for women were based on what were considered to be women's characteristics: manual dexterity, attention to detail, and lack of physical strength. ${ }^{41}$

Electronics producers also wanted women as part of their workforce because women were a much cheaper labor source. The industry's decentralized structure, as Ruth Milkman states, "reflected the industry's labor-intensity and the concomitant

41. Ronald W. Schatz, The Electrical Workers: A History of Labor at General Electric and Westinghouse, 1923-1960 (Urbana, IL, 1983), 30-33, 120; Milkman, Gender at Work, 15. 
pressure to depress wage levels." This decentralized structure allowed electrical companies to move into low-wage areas, open a small plant with only 300 to 500 employees, and hire a majority of women for employment. A good example of an industry in search of cheap labor was the RCA Company, which made a series of moves from Edison, New Jersey, to Bloomington, Indiana, to Memphis Tennessee, and finally to Ciudad Juarez, Mexico, hoping to cut labor costs and find the cheapest possible labor supply. Jefferson Cowie explains RCA's moves as a reinforcement of "the difference between highly skilled, hightechnology 'male' work and low-skilled, labor-intensive 'female' work by separating the two labor processes not just on the shop floor but by region and nation as well." 42

At first, companies hired only young, single women, because, during the first half of the twentieth century, it was customary for younger women to seek employment. Not until the 1950s did electronics companies begin hiring married women. Women worked in many different aspects of electronics production, especially on inexpensive consumer products such as light bulbs and radio tubes, areas where over 60 percent of the employees were women. Women were not limited to these "lighter" jobs, though; they also worked on assembly lines producing appliances.

Electronics work could be tedious, but it took a great deal of precision. Ronald Schatz describes the process of coil winding: "These workers wrapped wire, paper, and tape tightly around metal tubes to form the coils which are used to create magnetic fields in electric motors. The size of the coils depended upon the power of the motors in which they were placed: they ranged from an inch to several feet in length." It was also physically uncomfortable work. "Coil winders worked in a sitting position with little opportunity to move. Their fingers, wrists, arms, and shoulder muscles were continuously in motion." Much of the work in the industry was similar to this. Women usually sat at stations winding coils, assembling telephone relays, trimming small pieces of rubber, or drilling tiny pieces of metal. ${ }^{43}$

42. Milkman, Gender at Work, 15; Cowie, Capital Moves, 5.

43. Schatz, The Electrical Workers, 30. 


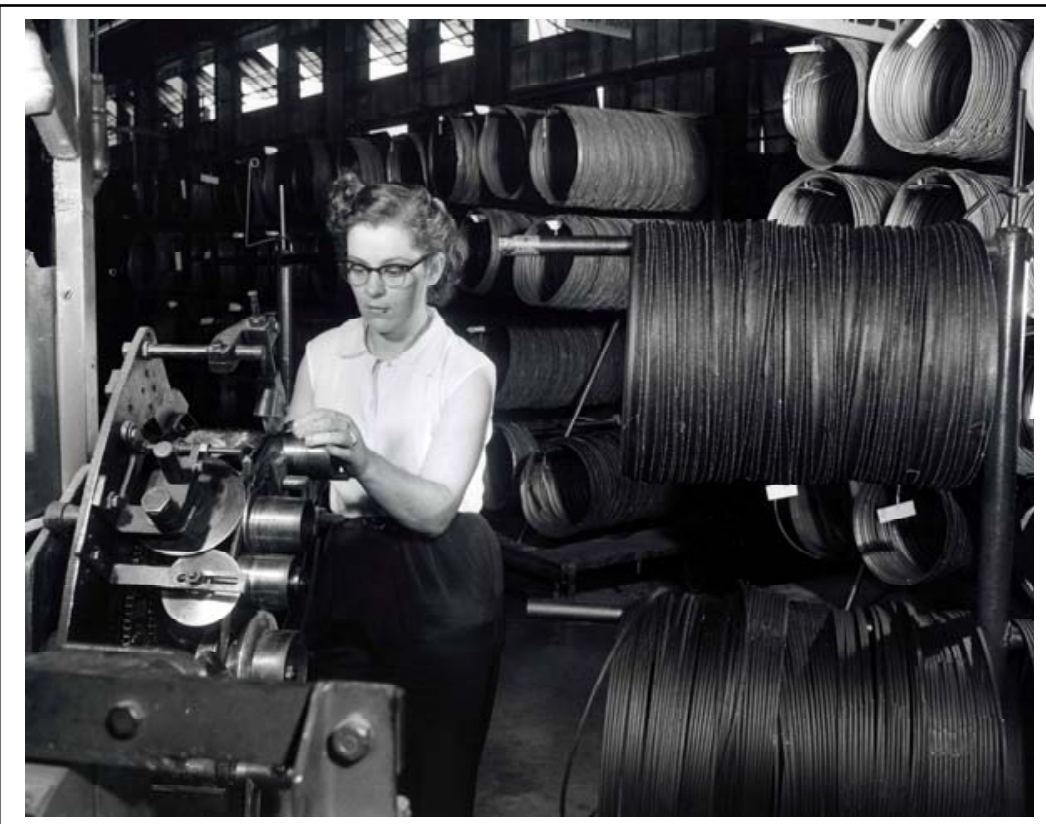

A woman does the fine work of coil winding in the electronics division of the Firestone plant in Des Moines, ca. 1960. SHSI-IC.

Electrical companies located in Iowa because it enabled them to cut production costs. Not all electrical plants in the state had migrated from elsewhere, however; several electrical companies were home-based industries that prospered due to the technological foresight of the inventors and the availability of a good labor source. Major home-grown industries included Maytag in Newton, Amana Refrigeration in the Amana Colonies, and Rockwell Collins in Cedar Rapids. Eventually, in the 1960s, all three were sold to major corporations as the original owners sought to retire and make a hefty profit off their businesses.

Electrical companies in Iowa produced a wide range of electrical equipment, from large appliances to tiny component parts such as radio tubes, and a majority of the companies hired women. For example, the Birtman Electric Company in Davenport hired about 150 women from 1949 to 1955. Not every woman stayed or even liked working there, and the company had issues with high turnover due to absenteeism, difficulties 
with child care, and the rough transition into production work, but many others decided to stay despite these complications. ${ }^{44}$ Another electrical company, Victor Radio, which built radio equipment, employed 60 women in a workforce of 200.

The appliance industry also employed a significant number of women. The best-known appliance company in Iowa was the Amana Refrigeration Company, located in the small cluster of villages known as the Amana Colonies. The company began when George Foerstner developed a new and more efficient way to produce refrigeration and freezers. He began using the new technology in the mid-thirties to produce freezers; by World War II, the business was booming and began expanding rapidly. Because the factory was located in a town of approximately 500 hundred residents, Foerstner needed to search outward for employees to produce the new, high-tech refrigeration products. He began drawing from a pool of rural and small-town residents from within a 40-mile radius surrounding Amana. Because filling the labor force was still difficult, he opened employment to women as well as men. From grievances and union lists from 1950 to 1965, it appears that at least 146 women worked at the plant. They commuted from about 21 small towns and communities, 16 of which had a population of less than a thousand. Women at Amana usually worked as lower-class assemblers, which meant work on the line, but some also worked as welders, painters, and inspectors. Amana provided a decent income for hundreds of rural women. Leona Roberts, a lifetime worker at Amana, noted, "I know if it hadn't been [for] Amana that come into this here territory, I don't know what people would have done around here because there was no jobs." 45

A handful of miscellaneous businesses also targeted a female labor force. A good example was the W. A. Sheaffer Pen Company in Fort Madison, located in the southeastern corner of the state along the Mississippi River. The company's founder, Walter Sheaffer, experimented with ways to develop fountain

44. Folders 6 and 7, box 6; folder 11, box 9; and folder 9, box 12, IAM Lodge 102 Records, SHSI.

45. Leona Roberts, Amana, interview by Janet Clements, 2/27/1995, ILHOP; folder 21, box 13, IAM Lodge 105 Records, SHSI. 
pens; in the early twentieth century he perfected a new process and cultivated a thriving business in pen production. His company continued to flourish. By 1952 the company built a new three-million-dollar plant in Fort Madison. It became one of the largest pen factories in the country, producing fountain pens, mechanical pencils, ballpoint pens, and customized desk sets. The company employed nearly 1,500 workers, about half of Fort Madison's total industrial workforce of 3,000. A majority of workers at the plant were women, because managers believed that women's small, nimble fingers were better suited to working with the small parts needed in pen manufacturing. Sandra Avery started working at Sheaffer in the 1970s putting plastic liners inside of pen caps, labeling pens, and spot-welding small pieces of metal. 46

Another employer of female workers was a rubber manufacturer in Keokuk, also located in the southeastern corner of the state a few miles from the Missouri border. Sheller Globe made synthetic rubber foam used in the auto industry, and produced the rubber insulation for windows and doors as well as rubber foam for arm rests and dash boards. Also known as Dryden Manufacturing, Sheller Globe started business in Keokuk in 1937 with only 50 employees. It grew rapidly, eventually employing more than 1,000 workers (40 percent of them female), making Sheller Globe the largest employer in Keokuk, a city with a population of about 16,000 and a manufacturing workforce of nearly 4,000. Women ran presses and completed the production process by putting the finishing touches on most of the products. Betty Noe worked as a cutter at Sheller Globe; using a pair of electric scissors, she trimmed the excess rubber from the final product. She described the process as having "so many angles in them that you must have the dexterity to be able to use a pair of sewing scissors, and that is almost duck soup for a woman to do." Women were paid based on a piecework system. Carrie Azinger, who operated a press within the factory, believed that piecework was the domain of women's work.

46. Sandra Avery, Fort Madison, interview by Merle Davis, 3/1/1983, ILHOP; Tom Cale, Fort Madison, interview by Merle Davis, 3/3/1983, ILHOP; Fort Madison vertical files, SHSI; Ted Sloat, Fort Madison: A Pictorial History (St. Louis, 1988). 


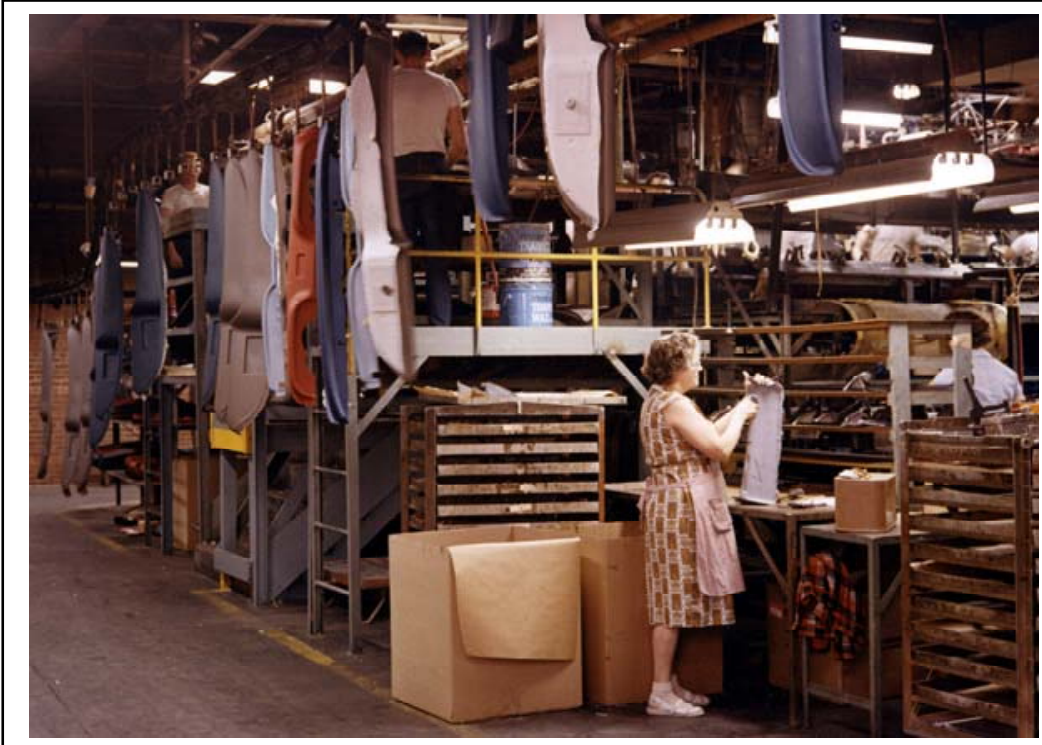

Women worked at the Sheller-Globe plant in Iowa City (shown here) as well as at the one in Keokuk. SHSI-IC.

She commented that "most of the men would be insulted if you mentioned-would you do this or that type of piecework. No way. They would take a straight-time pay rather than that. I think they felt that that was women's work." Men handled the heavier presses and other work deemed harder; not until the 1970s did women begin operating those jobs. 47

Many industries remained closed to women, and some actively weeded out all female employees who remained after World War II. The Clinton Corn Company in Clinton, for example, had hired a significant number of women during the war in order to keep up production while men served overseas. After the war, several women remained working in the plant, but they were segregated in the canning and sewing departments. During the 1950s, the company slowly removed the women, and from 1954 to 1960, they began to lay off most of

47. Carrie Azinger, Keokuk, interview by Merle Davis, 12/11/1981, ILHOP; Betty Noe, Keokuk, interview by Merle Davis, 12/10/1981, ILHOP; Keokuk vertical files, SHSI. 
the women. The few remaining female employees worked on the pudding line, canning and applying labels to the products. Several of the male employees began to object to women working on potentially male jobs, and William Skiff submitted a grievance objecting "to girls applying the label to . . . canisters for pudding powders in the package department." Skiff contended that the job was a man's job although it was being done by a woman. Management concluded that it was under the umbrella of men's work and that it should be done by a man. The company found yet another way to reduce the number of women working at the plant. By early 1951, all of the pudding packing jobs for women in the packing department were discontinued. The handful of remaining women were sequestered as janitors in sanitation or as seamstresses in the sewing room; combined, these two departments employed only a dozen women. The plant did not begin hiring women again until the 1970s, after the 1964 Civil Rights Act made it mandatory for it to do so. 48

Alcoa, an aluminum manufacturer, provides another example of discrimination against female workers. During the Korean War, Alcoa experienced a severe labor shortage. To maintain production, they began hiring women with the implicit understanding that they would be laid off once the war was over and production was down. Although the women were hired with the understanding that they would be the first to be laid off, they were still given seniority among themselves. The 300 women Alcoa hired drove fork trucks, operated cranes, and worked in the shipping department. They received the same pay as men. In 1957 the company laid off all of the female employees. Not only did the union fail to protect the interests of the female workers; it cooperated with the company from the beginning. According to Everett Shadle, when all the women marched into the union meeting demanding to get their jobs back, "We was the most no-good bastards ever was born in this country!" He claimed that it was the worst union meeting in his life. "There was a lot of women out there that were the best

48. Meeting Minutes, 1/19/1949, folder 1, box 22, American Federation of Grain Millers, Local 6, Records, SHSI. 
friends of mine. I thought that there was nothing I could do wrong, but I'll tell you that day I was the biggest s.o.b. that ever ... !" The women hired a lawyer and tried to sue the union and the company, but to no avail; they lost the case because they had been told when they were hired that they were subject to first layoff. Alcoa did not hire women again until the 1970s, after the Civil Rights Act went into effect. ${ }^{49}$

EACH OF THESE INDUSTRIES created space within their factories for female employment. This gave some guarantee to women that their jobs in the factory were secure, as long as they continued to work within designated female jobs. These highpaying, secure jobs pulled women into the factory because the jobs provided stability and income that helped support their families. Even though many industries, such as Alcoa and the Clinton Corn Company, remained closed to women, many more found women to be excellent employees, especially in the production of small parts. The electronics industry especially found women to be ideal employees, and as electronics boomed in Iowa, hundreds of Iowa women found work in the industry. It was these industries, with their steady work, benefits, and high wages that pulled women into the factory, and it was the national trend of women working outside the home that began pushing women out into the workforce. The congruence of these two factors led directly to the remarkable growth of women working in industry in the state, an important and dynamic change in the working lives of the female population of the state. These working-class women would create a distinctive workforce within Iowa factories. As women came from urban centers, small towns, and rural areas to work together in the factories, they would form a working-class consciousness based on a shared regional culture and common experiences on the factory floor.

49. Everett Shadle, Quad Cities, interview by Merle Davis, 3/13/1982, ILHOP. 